https://doi.org/10.48009/1_iis_2009_163-170

\title{
SERVICE LEARNING INTEGRATION USING INFORMATION SYSTEM COURSES
}

\author{
Gary J. DeLorenzo, California University of Pennsylvania, delorenzo@ cup.edu \\ Frederick G. Kohun, Robert Morris University, kohun@ rmu.edu \\ Alexis S. Macklin, Historical Society of Western Pennsylvania, asmacklin@hswp.org
}

\begin{abstract}
This paper details the experience of integrating service learning projects into technology oriented courses for the Computer Information Systems (CIS) program at California University of Pennsylvania (CUP) and the Communications and Information System Department at Robert Morris University (RMU). The paper entails the steps undertaken by faculty members at CUP to inquire, select and implement service projects in their technology courses and an example of one successful project for a non-profit organization. It also notes the findings and overall conclusions for the service learning initiatives that have occurred at $R M U$.
\end{abstract}

Keywords: Service learning, technology service projects, computer information systems

\section{INTRODUCTION}

Service learning is both a method of teaching and a way of learning that integrates community service with instruction designed to promote civic responsibly (Battistoni, 2002). Within this learning environment, educators facilitate students' engagement in problem-solving activities comprised of sensory awareness, emotions, physical conditions, and cognition (Carver, 1997). This theory builds on Dewey's (1916) concept of situational learning where learning is the result of interactions between the individual and the environment. The service experience provides both a process of acquiring new knowledge through refection, and an opportunity for further inquiry within the context of a given situation (Giles \& Eyler, 1994).

Stanton, Giles, and Cruz, (1999) indicated that service learning is an effective model for creating and studying a highly authentic learning environment, where instruction emphasizes the idea that much of what is learned is specific to the situations in which it is learned (Sweeney \& Paradis, 2004). These experiences include activities that are participatory, interactive, and representative of real-world events (Wenger, McDermott, \& Snyder, 2002). From an instructional perspective, learning is anchored in real contexts, where problem solving, critical thinking, and reflection are required (Howard, 1998).

Social interactions, which play a fundamental role in service learning activities, allow students to engage in debate, ask questions, state opinions, negotiate meanings, and resolve conflicts. All of these behaviors are believed to lead to reflection and internalization of new understandings (Brown, Metz, \& Campione 1996). In many ways, this is similar to Vygotsky's (1978) theory of social learning, which assumes that cognitive development occurs twice: first, between people (interpsychological) and then inside the individual (intrapsychological). A second aspect of Vygotsky's theory is the idea that the potential for cognitive development depends upon the "zone of proximal development" (ZPD): a level of development attained when people engage in social behavior. This theory assumes that skills developed with guidance or peer collaboration exceed what can be attained alone.

Peer feedback in service learning activities occurs when students observe each other testing, challenging, and revising ways of thinking about a particular problem. This iterative method of learning is critical to the formation of a collective knowledge base from which students are able gain deeper understandings of the thinking processes of the community. Social learning theory emphasizes the importance of observing and modeling the behaviors, attitudes, and emotional reactions of others (Brown \& Palincsar, 1989; Jonassen \& Henning, 1999). Bandura (1977) stated:

Learning would be exceedingly laborious, not to mention hazardous, if people had to rely solely on the effects of their own actions to inform them of what to do. Fortunately, most human behavior is learned observationally 
through modeling: from observing others one forms an idea of how new behaviors are performed, and on later occasions this coded information serves as a guide for action (p. 22).

\section{How service learning differs from traditional classroom experiences}

According to Weigert (1998), six elements differentiate and characterize service learning from traditional classroom experiences. Three of these elements focus on instruction: (1) the service flows from and into course objectives; (2) assignments requiring reflection integrate the service with course objectives; and (3) the assignment is assessed and evaluated. The other three elements focus on the community: (1) the service is meaningful to the community; (2) the service meets a need or goal; and (3) the community defines the need or goal.

McPherson (1996) identified the critical components for developing service learning activities that address all six of these elements:

- Service-learning activities maximize student participation in selecting, designing, implementing, and evaluating the service project.

- Service-learning activities value diversity in participants, practice, and outcomes.

- Service-learning activities promote communication and interaction with the community and encourage partnerships and collaboration.

- Students prepare for all aspects of their service work, including a clear understanding of the task, the skills and information required to complete the task, awareness of safety precautions, and knowledge about and sensitivity to colleagues.

- Student reflection takes place before, during, and after service; uses multiple methods to encourage critical thinking; and is central in the design and fulfillment of curricular objectives.

- Multiple methods are designed to acknowledge, celebrate, and validate student service work.

Essential for quality service learning instruction is the development of clear educational goals that require students to construct their own knowledge and understandings about a given problem. Lesh (2002) explained that to learn about the nature of students' developing knowledge, it is useful to focus on tasks in which the resulting products demonstrate significant information about the ways of thinking that produced them. This means that students need to be able to communicate how they interpreted a task or problem-solving situation. Within a service learning project, students plan problemsolving strategies, challenge ideas, monitor progress, test various solutions, and explain outcomes to each other. As students make sense of their experiences through testing, reflecting, modifying, and refining their thinking, knowledge is constructed.

\section{Criticisms of Service Learning}

Currently service learning is gaining popularity in higher education, but there are some who do not agree with the practice (Mattson, 1998). These critics contend that the service component waters down the curriculum, further weakening the quality of higher education, and that the time students spend volunteering in community agencies as part of a course might be better spent in the library or laboratory (Gray, Ondaatje, \& Zakaras, 1999). To address this concern, Battistoni (2002) emphasizes the importance of selecting placements intentionally to meet the learning objectives of the course. The organization benefiting from the service should be considered a partner in education providing structured opportunities for students to critically reflect on the civic nature of their experience.

Manchester and Baiocchi (2001) question if service learning can do more harm than good when the motive to serve may supersede the needs as defined by the community being served. In other words, what is more important - the instruction or the service? Is it really possible to meet both the intended learning objectives and the community's needs? Howard (1998) argues that it is essential to create opportunities that are relevant and meaningful to both the community and the students. The purposeful planning, design, and implementation of activities around specific learning objectives should be done in collaboration with the community benefiting from the service to avoid conflicts between instructional and service objectives. Benefits of service learning; strategies for
implementation 
Research indicates that well-implemented service learning programs support the long-term development of civic responsibility, while the impact of the activities address immediate intellectual and social benefits for students and the communities they serve (Billig \& Furco, 2002; Mendel-Reyes, 1998). Roehlkepartain (2007), however, cautioned that positive outcomes are not automatic and will vary depending on the focus, scope and quality of the learning experience. He identified specific benefits for each stakeholder (students, campus, and community) to use as a benchmark for success, including:

- Service-learning gives an intentional strategy for addressing goals for learning and personal development through civic engagement and community service.

- Service-learning cultivates connections between the organization, schools, higher education, and other community groups.

- Service-learning increases program staff and volunteers' level of engagement, leadership capacity, and satisfaction with their work.

- Service-learning reinforces effective development practices, providing appropriate structure, supportive relationships, opportunities to belong, positive social norms, opportunities for skill building; and integration of school and community efforts.

In order to build an effective program that can attain benefits for each stakeholder, there must be: (1) teacher commitment; (2) a mutually beneficial partnership between the school and the community agency; (3) institutional commitment. The collaborative relationships fostered in this learning environment should be maintained through formal agreements and memorandums of understanding that clearly articulate the roles and responsibilities for each partner. Abregana (2006) suggested four different models for addressing these roles and implementing a service learning curriculum: (1) as part of a course, (2) as a specially designed course, (3) as a departmental program, or (4) as a departmental program in collaboration with partner agencies.

\section{SERVICE LEARNING PROJECT - THE CUP CASE STUDY}

\section{Motivation and Significance:}

Volume X, No. 2
This project provided substantial benefits for the students and the nonprofit organization, the Historical Society of Western Pennsylvania (HSWP). As noted above, it used Abregana's model to implement a service learning curriculum "as part of a course" objective. For this case study, the students' service learning opportunities were gained, outside the classroom, by interviewing users and archivists to gain an understanding of the requirements to improve process work flow. The overall goal was to integrate the requirements into the design, development and implementation of an information system solution in order to gain productivity improvements. Oftentimes in academic settings, students in technical programs do not get the chance to enhance their soft skills (e.g., communication, interviewing, and understanding group dynamics). This service learning project helped students to strengthen their soft with hard skills (e.g. programming and database development) while getting practical experience in applying the systems development lifecycle to practical information management problems [Schwalbe].

HSWP is a non-profit educational institution that has provided continuous service to Pittsburgh and the Western Pennsylvania region since 1879. HSWP operates the Senator John Heinz Pittsburgh Regional History Center (Heinz History Center), the largest history museum in Pennsylvania, which opened to the public in 1996 in downtown Pittsburgh.

Since August 2005, collaborative efforts between the Heinz History Center and California University of Pennsylvania's Mathematics and Computer Science Department has resulted in the creation of a "volunteer applications development" group with students and faculty from the university. Each semester, through the guidance of Computer Information System faculty members, students provide information technology support services to the Heinz History Center on projects ranging from providing training classes in the use of MS Office 2007 or creating customized reporting and queries via MS Access 2007 against archived collection data. One specific collaborative effort was during the fall 2007 and spring 2008 semesters where three students developed a database application to help researchers and archivists track, manage and report over 1,000 films donated by the Westinghouse Electric Corporation as part of their capstone CSC490 
and CSC492 Senior Project I and Senior Project II course requirements.

\section{Project Background:}

The L\&A users in were looking for a better and more efficient method to track archival collection, which will benefit not only themselves but also the community and academic researchers. They were looking for a database management system to track the condition and content for the Westinghouse films. By improving tracking and reporting methods, film collections would be more accessible to researchers investigating the Westinghouse Electric Corporation.

One primary objective of the project was to remove the unstructured workflow where researchers and archivists had Excel spreadsheets and paper documents to track the Westinghouse films and replace the workflow with one, holistic centralized database and reporting solution for the organization. The intent for the project, which was attained, was for students to define and build a front-end application to enter and maintain the film collection data and also provide standard reporting solutions via queries and customized reports.

Outcomes gained from the project provided the students experience in building computer information systems, where they received

- exposure to the "social networking" side of analysis and design by understanding the interpersonal skills needed for interviewing, and

- experience in building technically based computer systems that are used in problem solving and decision making in the workplace.

Students participated in all levels of the systems development lifecycle (planning, analysis, design, development, and implementation) by working closely with researchers and archivists. As noted by researchers in the information systems area [Schwalbe], the high failure rate for information systems design projects is due to the lack of understanding of the system from the end users' perspectives because the designer tends to view the project from a technical perspective. This project helped to alleviate that problem while exposing students to applied, practical field experiences.

\section{Description of Prior Workflow and Project Solution}

The Heinz History Center uses a computer based information system, BiblioMondo, which provides access to collection holdings. While considered a leading solution for cataloging materials, it is primarily used for books and monographs. It does not meet the needs of researchers and archivists in tracking and managing three-dimensional objects and artifacts such as clothing, household items and films, and does not provide required donor data attributes. $M$ museum researchers Gilliland-Swetland and Chandler noted techniques to make these collections accessible through products such as BiblioMondo, but the descriptions are often too generalized and do not include adequate information technology based solution. For this project, students analyzed the retrieval and reporting needs of the researchers and archivists as the basis to define the data to store within a centralized, normalized database management system. Once an understanding of the data requirements were captured, the students concentrated on data entry forms for data entry and standard reporting and queries for output.

Table 1 captures at a summary level the accomplishments of the students through the systems development lifecycle. The table notes the work breakdown structure of activities, the timeline in the semester that the work was accomplished, and the overall outcomes and deliverables provided by the students. In essence, it captures the project management overview and final synopsis of the project. Starting in the fall 2007 semester, three (3) students began the information gathering and requirements definition for the project as the overall project team. The students collaborated on activities such as project management, systems analysis, database and application design and development. The deliverable at the end of the semester was a systems design document with specs on the new information system solution. Beginning with the winter 2008 semester, the same three (3) students developed the database and application interface system which resulted in user testing and application acceptance in April 2008. In May 2008, the students provided training to the researchers and archivists on the usage of the Westinghouse film database application. Actual film attributes were keyed via the data entry forms, and initial reports and queries were generated. With an enthusiastic response from the users, it was 
agreed that the information system more than adequately met their requirements, and operational processes were implemented to use the system on a day-to-day basis for film tracking and reporting. Feedback from the students confirmed that the project had remarkable value in gaining actual field experience in developing computer based information systems. The opportunity to create a user accepted technical solution, while balancing analysis, critical thinking and interpersonal communication skills, was a major success for the students in this service learning endeavor.

Table 1: Systems Development Life Cycle:

\begin{tabular}{|l|l|l|l|}
\hline Phases & $\begin{array}{l}\text { Work } \\
\text { Breakdown }\end{array}$ & Timeline: & Outcomes \\
\hline $\begin{array}{l}\text { Phase I: } \\
\text { Anvestigation and }\end{array}$ & $\begin{array}{l}\text { Reviewed the existing process to maintain } \\
\text { multiple Excel spreadsheets and defined } \\
\text { the reporting problems associated with } \\
\text { the current process. }\end{array}$ & $\begin{array}{l}\text { September } \\
2007\end{array}$ & $\begin{array}{l}\text { Project Proposal Document by } \\
\text { students: Confirmed project } \\
\text { objectives and scope. }\end{array}$ \\
\hline $\begin{array}{l}\text { Phase II: User } \\
\text { requirements, } \\
\text { technical specs }\end{array}$ & $\begin{array}{l}\text { Defined the reporting needs of the } \\
\text { researchers and archivists and the } \\
\text { technology needed for the new system. }\end{array}$ & $\begin{array}{l}\text { November } \\
2007\end{array}$ & $\begin{array}{l}\text { User needs, technical spec docs } \\
\text { by students: received archivists' } \\
\text { and faculty approval. }\end{array}$ \\
\hline $\begin{array}{l}\text { Phase III: } \\
\text { Database and } \\
\text { application } \\
\text { development }\end{array}$ & $\begin{array}{l}\text { Built and constructed the database and } \\
\text { application solution. MS SQL Server } \\
\text { 2005 for the centralized database, and } \\
\text { either MS Access 2007 or Visual } \\
\text { Studio.Net for the front end application to } \\
\text { maintain data, generate reports. }\end{array}$ & $\begin{array}{l}\text { December } \\
2007 \\
\text { January 2008 }\end{array}$ & $\begin{array}{l}\text { Students began migration of } \\
\text { individual dabases into } \\
\text { centralized solution. Students } \\
\text { developed summary and detailed } \\
\text { reports. Review and approval on } \\
\text { completed work. }\end{array}$ \\
\hline $\begin{array}{l}\text { Phase IV: User } \\
\text { testing and } \\
\text { acceptance }\end{array}$ & $\begin{array}{l}\text { Created a system test plan for archivists } \\
\text { and researchers to review the screens and } \\
\text { reports to test for adequacy. This phase is } \\
\text { an iterative process where versions of the } \\
\text { system were reviewed to ensure that the } \\
\text { solution met the project scope and their } \\
\text { business needs. }\end{array}$ & $\begin{array}{l}\text { February } \\
2008-\end{array}$ & $\begin{array}{l}\text { Students installed database and } \\
\text { application at the History Center. } \\
\text { Archivists and researchers } \\
\text { reviewed the system with } \\
\text { approval or disapprove on } \\
\text { adequacy of system. Change } \\
\text { requests were captured by the } \\
\text { students as enhancements. }\end{array}$ \\
\hline $\begin{array}{l}\text { Phase V: } \\
\text { Implementation, } \\
\text { Documentation }\end{array}$ & $\begin{array}{l}\text { Moved the solution into production, for } \\
\text { use in day-to-day operations by the users. }\end{array}$ & April 2008 & $\begin{array}{l}\text { Students: User manual and } \\
\text { system procedures were created. } \\
\text { Implemented system at the } \\
\text { Center. }\end{array}$ \\
\hline
\end{tabular}

\section{SERVICE LEARNING AT RMU WITH RMU ENGAGEMENT TRANSCRIPT}

While service learning provides an added and important dimension to the education process for which most students admit to being life changing, there may be a difficulty in initially getting students involved. RMU in recognizing this potential difficulty has taken on two different yet complementary approaches to enhance student involvement. One approach has been to directly include a service learning semester long project in required courses. As an example, a public relations course-required for the communications major-incorporates a

Volume X, No. 2 service learning project to establish needs and plans for a public relations program for a local community. Students attend council meetings, and school board meetings as well as specialized meetings with community leaders to access the current situation, needs, and long term goals. Then, as a class project, the students design, develop, and implement a viable public relations program that includes a strategy, a budget, and time table for implementation. The next group of students takes on the role of implementing the program. This approach actively involves students as a course and academic program requirement. 
The second approach involves an institutional commitment to student involvement in the community as part of their educational experience. While all colleges and universities have established academic transcripts as a way to validate and verify academic experiences, RMU has yet another institutional transcript. This second transcript is the Student Engagement Transcript (SET). Beginning fall 2009, as a graduation requirement, all students must have involvement in at least three activities that can be validated, documented, and eventually listed on the official university Student Engagement Transcript. The student activity can be chosen from five categories to fulfill the graduation requirement. The categories include:

- Arts, Culture and Creativity: Students with earned entries in this category completed activities deemed to be creative in nature. Examples include the production of creative work such as visual art, electronic and digital media, design work, poetry, musical compositions, etc.

- Leadership: Students with earned entries in this category interacted with a variety of people from culturally diverse backgrounds by participating in study abroad programs, international faculty-led trips, and cultural immersion experiences.

- Undergraduate Research: Students with earned entries in this category conducted undergraduate research that transcended traditional classroom assignments. Students may have presented their work at research conferences or seminars, published in an appropriate academic journal or periodical, etc.

- Professional Experience: Students with earned entries in this category participated in professional experiences such as internships, cooperative opportunities, practicums, or clinical.

- Special Recognition, Special Projects and Participation: Students with earned entries in this category accomplished one of the following: certificates, awards, innovative projects, and co-curricular activities such as athletic teams, campus organizations, or task forces for special university events and programs.

- Service: Students with earned entries in this category donated their time and talents in partnership with University-approved nonprofit organizations or governments.

While the SET will not be required until Fall 2009 , nearly $40 \%$ of students graduating in May 2008 voluntarily have requested participation with the SET. Of those students, most had used service in the form as service learning as one of their transcripted entries.

The purpose of the SET is two-fold. One is to encourage student participation in the community as an important and life changing part of their education. The other purpose is to provide future employers with yet another dimension of the graduate they are considering to hire. SET demonstrates attributes that go beyond meeting the minimum academic requirements of an education. It also officially validates and verifies information they are very much interested in that is an indicator of leadership, social responsibility, and the ability to work well with others.

\section{SUMMARY AND FUTURE RESEARCH}

This paper introduces faculty and researchers on various service learning projects and their usage within technology-based courses. A case study focused on courses, programs, and institutional requirements offered by the Computer Information Systems program at California University of Pennsylvania and at Robert Morris University.

While these projects were well-received where students actually developed an information system solutions to improve process efficiencies within organizations, there is a need to encourage even greater student participation and to widen the experience of introducing service projects into technology courses and research its effectiveness. Embedding service learning into core course of the curriculum and institutional commitment to student learning such as the Student Engagement Transcript may enhance both student numbers and commitment to service learning projects. The authors of this paper 
recognize that these projects were examples of initial efforts to bring service learning projects to bear within their respective university. Thus, it is our intention to conduct a more comprehensive study that addresses the types of projects undertaken, the outcomes of these projects, and student performance in subsequent courses (courses taken after a service learning experience). The future work will include feedback from the students, as well as the service organization, to provide a benchmark on the value-added results from the service learning initiative and its relationship to future courses that offer service projects in technology-based programs.

\section{REFERENCES}

Abregana, B. (2006). Service learning as a new pedagogy in higher education. Surabaya:

National Seminar on Service Learning.

Bandura, A. (1977). Social learning theory. New York: General Learning Press.

Battistoni, R.M. (2002). Civic engagement across the curriculum: A resource book for service-learning faculty in all disciplines. RI: Campus Compact.

BiblioMondo (2008), “A New Generation of Library Technologies", BiblioMondo ISACS Software. Retrieved 7 Dec. 2008 http://www.bibliomondo.com

Billig, S., \& Furco, A. (2002). Service-learning through a multidisciplinary lens: Advances in service-learning research. Greenwich, CT: Information Age.

Brown, A. L., Metz, K. E., \& Campione, J. C. (1996). Social interaction and individual understanding in a community of learners. The influence of Piaget and Vygotsky. In A. Tryphon \& J. Voneche (Eds.), Piaget-Vygotsky: The social genius of thought (pp. 145-170). New York: Psychology Press.

Brown, A. L., \& Palinscar, A. M. (1989). Guided, cooperative learning and individual knowledge acquisition. In L. B. Resnick (Ed.), Cognition and instruction: Issues and agendas (pp.

Volume X, No. 2
393-451). Hillsdale, NJ: Lawrence Erlbaum.

Carver, R.L. (1997). Theoretical underpinnings of service learning. Theory into Practice, 36(3), 143-149.

Dewey, J. (1916). Democracy and education: An introduction to the philosophy of education. New York: Macmillan.

Giles, D.E., Jr., \& Eyler, J. (1994). Theoretical roots of service learning in John Dewey: Toward a theory of service learning. Michigan Journal of Community Service Learning, (Fall), 77-85.

Gilliland-Swetland, Anne J., Robin L. Chandler, and Layna White. "MOAC II User Evaluation: Making Museum Content Useful," in Proceedings of the $66^{\text {th }}$ Annual Meeting of the American Society for Information \& Technology -

Humanizing Information Technology, Long Beach, California, October 20 23, 2003 (Medford, NJ.: Information Today, 2003).

Gray, M. J., Ondaatje, E. H., \& Zakaras, L. (1999). Combining service and learning in higher education. Summary report. Santa Monica, CA: Rand.

Howard, J.P.F. (1998). Academic service learning: A counternormative pedagogy. In R.A. Rhoads \& J.P.F.Howard (Eds.), Academic service learning: A pedagogy of action and reflection (pp. 21-29). San Francisco: Jossey-Bass Publishers.

Jonassen, D., \& Henning, P. (1999). Mental models: Knowledge in the head and knowledge in the world. Educational Technology, 39(3), 37-42.

Lesh, R. (2002). Research design in mathematics education: Focusing on design experiments. In L. English (Ed.), International handbook of research design in mathematics education (pp. 27-51). Mahwah, NJ: Lawrence Erlbaum. 
Manchester, H., \& Baiocchi, L. (2001). Currents: The Newsletter of Youth Service California, Volume IX, Number http://www.energizeinc.com/art/vvser.ht $\mathrm{ml}$

Mattson, K. (1998). Can service-learning transform the modern university? A lesson from history. Michigan Journal of Community Service-Learning, 5(Fall), 108-113.

McPherson, K. (1996) Service-learning: Getting to the heart of school renewal. Vancouver,WA: School Improvement Project.

Mendel-Reyes, M. (1998). A pedagogy for citizenship: Service learning and democratic education. In R.A. Rhoads \& J.P.F.Howard (Eds.), Academic service learning: A pedagogy of action and reflection (pp. 31-38). San Francisco: Jossey-Bass Publishers.

Roehlkepartain, E.C. (2007). Benefits of community-based service-learning. Scotts Valley, CA: Learn and Serve America's National Service-Learning Clearinghouse. http://servicelearning.org/instant_info/fact sheets/cb facts/benefits cbosl/index.php

Schwalbe, Kathy. Information Technology Project Management, $5^{\text {th }}$ edition, Boston, MA: Course Technology, 2007

Stanton, T.K., Giles, D. E., \& Cruz, N.I. (1999) Service-learning: A movement's pioneers reflect on its origins, practice, and future. San Francisco: Jossey Bass Publishers.

Sweeney, A. E., \& Paradis, J. A. (2004). Developing a laboratory model for the professional preparation of future science teachers: A situated cognition perspective. Research in Science Education, 34, 195-219.

Vygotsky, L. S. (1978). Mind in society. Cambridge, MA: Harvard Press.

Weigert, K.M. (1998). Academic service learning: Its meaning and relevance. In R.A. Rhoads \& J.P.F.Howard (Eds.),
Academic service learning: A pedagogy of action and reflection (pp. 3-10). San Francisco: Jossey-Bass Publishers.

Wenger E., McDermott, R., \& Snyder, W. M. (2002). A guide to managing knowledge: Cultivating communities of practice. Cambridge, MA: Harvard University Press. 